\title{
Biological Features and Productivity of Drought-Tolerant Fodder Plants under the Conditions of the Adyr Zone of Uzbekistan
}

\author{
Khaydarov Kh. (Corresponding author) \\ Samarkand State University, Samarkand, Uzbekistan \\ E-mail: haydarov@rambler.ru \\ Mukimov T. \\ Samarkand State University, Samarkand, Uzbekistan \\ Islamov B. \\ Samarkand State University, Samarkand, Uzbekistan \\ Nurullayeva N. \\ Samarkand State University, Samarkand, Uzbekistan
}

\begin{abstract}
The article presents the results of the state of foothill pastures of the Kamashi district of the Kashkadarya region and ways to restore degraded territories by introducing drought-tolerant perennial species of fodder plants, increasing the biological diversity of fodder species.
\end{abstract}

Keywords: degradation, desertification, biology, long-term drought-resistant forage crops, productivity, technologies, seeds

DOI: $10.7176 / \mathrm{JSTR} / 6-08-04$

\section{Introduction}

An increase in the number of livestock and an increase in sheep productivity depend almost entirely on the state of pasture grass and the nutritional value of fodder vegetation. All this affects the decrease in the natural productivity of pastures, the occurrence of varying degrees of their degradation and soil erosion.

The yield and nutritional value of forage grasses in the foothill desert varies by year and season. The average annual yield in adverse years is $121 \mathrm{~kg} / \mathrm{ha}$, and a maximum of $700-800 \mathrm{~kg} / \mathrm{ha}$. The most is the spring season, when there is a rapid vegetation of pasture plants, their nutritional value is high: $1 \mathrm{~kg}$ of absolutely dry food of the foothill desert in spring (unfavorable year) contains 0.79 feed units; $9.88 \mathrm{MJ}$ of exchange energy, $86 \mathrm{~g}$ of protein, in winter, respectively, $0.44 ; 7.44$; and 31.9 . In the spring (unfavorable year), the nutritional value of herbs was 0.81 feed units, $10.0 \mathrm{MJ}$ and $90.0 \mathrm{~g}$ of protein. In subsequent seasons, a decrease in the total and protein nutrition of the feed is observed.

Overgrazing of pastures and unsystematic use of them leads to increased degradation of vegetation and soil cover. Negative natural factors - meteorological and exogenous - lead to erosion destruction of lands and a decrease in their soil fertility. In the occurrence and course of desertification processes, along with human economic activity, an important role is played by natural factors:

- climate aridity, deflation processes, soil salinization, sparse vegetation

Naturally, the solution of the above problem is impossible without the development and implementation of a rational pasture management system, improving the skills of farmers by demonstrating the best management practices and advanced practical knowledge applied in countries with a developed livestock sector.

The way to revitalize pastures is to determine and allocate the necessary area of pastures, establish its botanical composition, yield of eaten mass and capacity by season of the year, compile and universally introduce pasture rotation, establish a balance of feed with the definition of the missing part and sources of their acquisition. 
Overgrazing of pastures and unsystematic use of them leads to increased degradation of vegetation and soil cover. Negative natural factors - meteorological and exogenous - lead to erosion destruction of lands and to a decrease in their soil fertility.

Purpose of the study. The current state of arid pastures, unfortunately, does not meet the challenges of the further development of animal husbandry. For the successful development of animal husbandry, it is necessary to constantly study the state of pastures, monitor its biodiversity, identify the causes of degradation, develop measures to prevent them, introduce environmental technologies for keeping and grazing animals, create highly productive and long-term pastures that would ensure year-round grazing and balanced feeding of animals.

Materials and research methods. Route field studies with the description of sample plots by the traditional method, full-scale interpretation of satellite images. Identification of types of pastures and determining the yield of forage mass in the trial plots according to the seasons of the year. Assessment of the degree of degradation of pasture vegetation cover [2].

Assessment of the state of pastures was carried out on a typical vegetation cover and topography characteristic for foothill pastures areas. On the selected pasture sites, studies of the vegetation cover were carried out: geobotanical descriptions, vegetation cuttings, the parameters of the projective cover and the number of dominant plant species were determined.

Results and Discussion. Pastoral livestock breeding in its essence should mainly be based on pasture forage; however, pasture productivity largely depends on climatic conditions (temperature, rainfall by season of the year, etc.) and can vary greatly both by year and season. Therefore, livestock and pasture management should be based on feed balance, that is, the need for animals in feed should be equal to the presence of feed on pastures. According to long-term data, sheep and goats on average from 50\% (low yield) to $90 \%$ (high yield) can provide the need for feed in the late spring and summer-early fall periods, due to pasture, the rest of the time additional feeding is required. These feeds must be procured locally, which, due to a non-sustainable climate, is impossible to fulfill or must be purchased on the market. [5] An increase in the number of livestock and an increase in sheep productivity depend almost entirely on the state of pasture grass and the nutritional value of fodder vegetation. But these factors are ambiguous in desert - pasture livestock breeding. In good, favorable years, the grass yield in the pasture reaches $300-400 \mathrm{~kg} / \mathrm{ha}$ of dry mass, and in unfavorable years only $80-150 \mathrm{~kg} / \mathrm{ha}$. [6]

Ceteris paribus, feed reserves during the year also fluctuate greatly, decreasing by 2.5 times by winter, their nutritional value is particularly sharply reduced. $100 \mathrm{~kg}$ of pasture feed in spring contains $80-90$ feed units, and in winter 18-25 feed units

The low feed productivity of natural pastures (about 105-300 kg / ha of hay in meteorological averages), creates certain difficulties in the optimal development of animal husbandry in this natural zone. This problem, as shown by many years of experience in research in desert-pasture livestock, can be solved by improving them. In particular, in relation to some pasture arrays, the creation of protective plantations and pasture agrophytocenoses from various plant life forms gives a good effect.

Superficial improvement of pastures allows, without disturbing the vegetation cover, introducing new fodder crops and increasing the density of grass stands. Pasture agrophytocenoses, consisting of a mixture of various life forms (shrubs, semi shrubs, grasses) make more rational use of the water and mineral resources of the environment and more fully satisfy the animal's requirements for feed diversity.

As part of the GEF / FAO project "Supporting Solutions for the Promotion and Dissemination of Sustainable Land Management of SLM in Uzbekistan" on the lands of "Altinbaev Yeri" farm in the Kamashi district of the Kashkadarya region, a primary seed plot has been created for promising droughtresistant crops used to restore degraded pastures. Shrubs - Haloxylon aphyllum, semi shrubs - Kochia prostrata, Halothamus subaphylla, Atriplex undulata, Ceratoides Ewersmanniana, grasses - Climacoptera lanata, Onobrychis horossanica, Agropyron desertorum.

Ceratoides eversmanniana Botsch, et Ikonn. A semi shrub from the Chenopodiacea family. The root system of Ceratoides eversmanniana in the culture is powerfully developed, has a large number of welldeveloped lateral roots. Ceratoides eversmanniana is exceptionally drought and heat-resistant to diseases and pests. Among arid fodder plants, it is highly resistant to trampling (pasture tolerance). Plant height $65-85 \mathrm{~cm}$, bushiness (number of shoots in the bush) -high (70-80 generative shoots). The foliage is good (45-55\% of the total above-ground phytomass). Plants are well eaten by farm animals, especially karakul sheep and goats. The fodder mass contains: crude protein $-12-13 \%$ fiber $-25-27 \%$. $100 \mathrm{~kg}$ of feed contains 41-43 feed units. Ceratoides eversmanniana is a long-growing plant, the growing season is 230-

35 | P a g e

www.iiste.org 
240 days. The yield of dry fodder mass is $1.12-1.25 \mathrm{t} / \mathrm{ha}$, the seed yield is $0.12-0.17 \mathrm{t} / \mathrm{ha}$. Unlike other varieties, Ceratoides eversmanniana seeds retain viability for up to 2.5 years. It withstands competition in co-growth with other species of fodder plants. Productive longevity is 17-23 years, recommended for cultivation (in the creation of artificial hayfields and pastures) in the arid zones of Uzbekistan with an amount of precipitation of 160-340 $\mathrm{mm}$ per year.

Kochia prostrata (L) Schrad. - a semi shrub from the family - Chenopdiaceae, 30-75 cm high, often reaches $60-90 \mathrm{~cm}$ in culture. Kochia prostrata is an ecologically plastic plant; it grows in light soils, light and typical gray soils of various mechanical composition: gray - brown and sandy soils.

Kochia prostrata develops a powerful deeply penetrating (up to 5-6 m) root system of a universal type, uses moisture from a large volume of soil. This drought-tolerant plant, sparingly consumes moisture for transpiration, which requires heat and light, can withstand average salinity of the soil. Kochia prostrata is a widespread plant in the arid regions of Central Asia, Kazakhstan and the South - East of Russia. Productive longevity of 15-20 years. The maximum yield of fodder mass and seeds in the culture are observed for 3-4 years of life.

In the conditions of culture, during the years it is favorable and medium in terms of humidification bears fruit in the first year of life. Seed yield under conditions is over $100 \mathrm{~kg} / \mathrm{ha}$; and on production crops within $80 \mathrm{~kg} /$ ha. The mass of 1000 seeds is $1.19-1.3 \mathrm{~g}$. The reproduction rate varies from 7 to 58 . The seeds are very pubescent, low-flowing. [7]

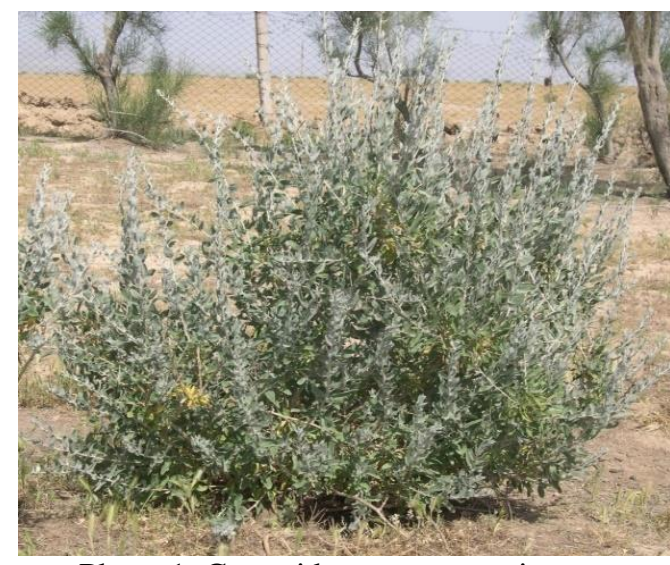

Photo 1. Ceratoides ewersmanniana

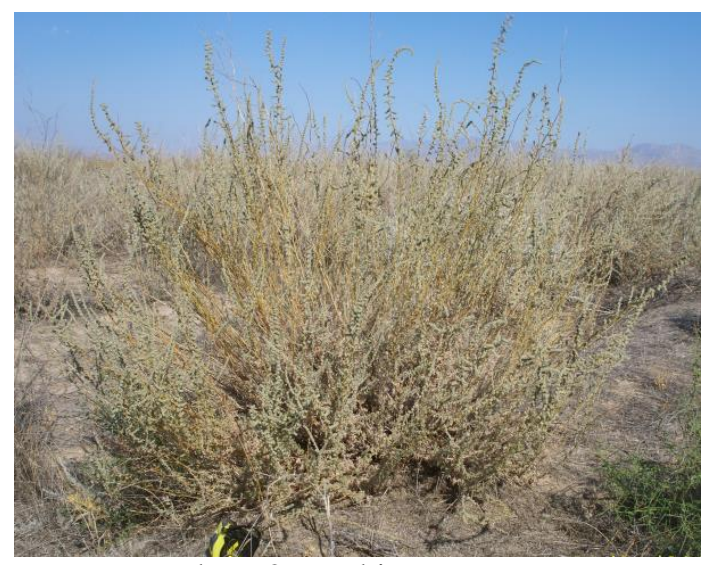

Photo 2. Kochia prostrata

Artemisia diffuza H. Krasch. A semi shrub from the family Compositae, 20-60 cm high. Vegetation begins in late February and early March. The leaves are small, very rugged, spreading up to the root neck. It grows until June, in the hot summer months, stops growing and developing, falls into a state of suspended animation, leaves are falling.

In September, wormwood plants grow leaves, and vegetation continues. It blooms in September and October, in November the seeds ripen. Well propagated by seeds. The composition of wormwood contains bitter substances, glucoside, resin, tannins, organic acids, 0.2-0.45\% essential oils and $100 \mathrm{mg} \%$ vitamin C. On pastures, the life expectancy is $12-25$ years. The growing season is $240-280$ days, the root system penetrates to a depth of $2.5 \mathrm{~m}$. In desert animal husbandry, wormwood is one of the best fodder plants. $100 \mathrm{~kg}$ of hay for the phases of vegetation contains 18-66 feed units. In many pastures, the basis (more than $50 \%$ of the gross stock) of feed is wormwood. On some types of pastures, the wormwood yield is $0.8-1.0 \mathrm{t} / \mathrm{ha}[1]$. 


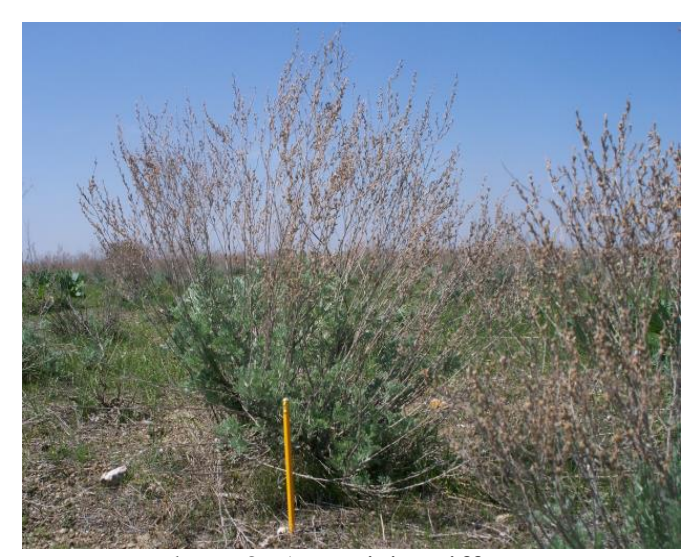

Photo 3. Artemisia Diffusa

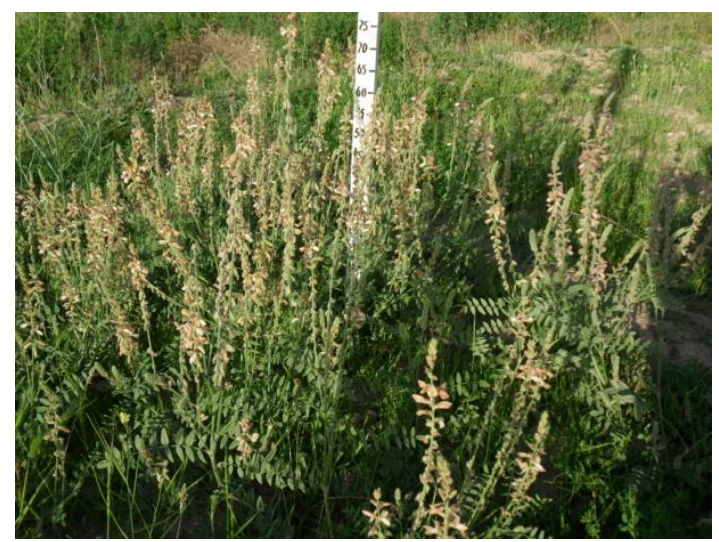

Photo 4. Onobrychis horossanica

Species of the genus Cousinia and the genus Lycium of the introduced plant Lycium barbarum L., L. dasystemum Pojark., L. ruthenicum Murr., L. turkomanicum Turez, are very promising for growing in the foothills of Uzbekistan.

Cousinia decurrens is a plant from the family Asteraceae, grows on adyrs of foothill semi-desert and areas of southern deserts. Fodder and hay mass gives in the second year of vegetation. Sheep is hardly eaten on pasture, but it is harvested for winter feeding. The best time for harvesting is the phase of budding and the beginning of flowering (May-June). Sheep eats well in shredded and moistened hay, as well as in silage. It grows from March to mid-June. [5]

Lycium barbarum $\mathbf{L}$. The effective use of plant materials for food, pharmacy and medicine in order to improve the welfare of the population is a very urgent problem. Common Lycium barbarum L. is a perennial branched shrub 1-2.5 m tall of the family Solanaceae. The fruits of Lycium barbarum L. have been widely used in Chinese medicine for 2,000 years, and have been used in medicine to improve the immune system, increase visual acuity, prevent liver diseases and improve blood circulation. In particular, the plant antioxidant properties of this plant are appreciated. Ingredients, such as polysaccharides, beta-carotene, vitamin E, phenols, zeaxanthin and flavonoids in fruits, provide antioxidant properties and prevent aging and prevent the dangerous growth of cancer. Berries of ordinary L. barbarum are widely used in traditional medicine in a number of countries (China, USA, Argentina, etc.) as an immunomodulators. There is information about the high antitumor and antioxidant activity of common L. barbarum. Extracts from the roots exhibit antihypertensive, antifungal and anti-inflammatory effects. Based on this, the study of ordinary L. barbarum is of scientific and practical interest to expand the range of domestic herbal remedies. [4].

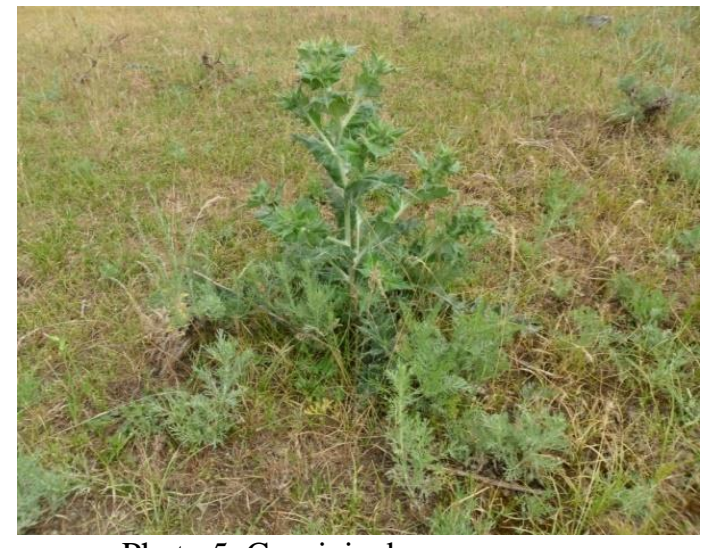

Photo 5. Cousinia decurrens

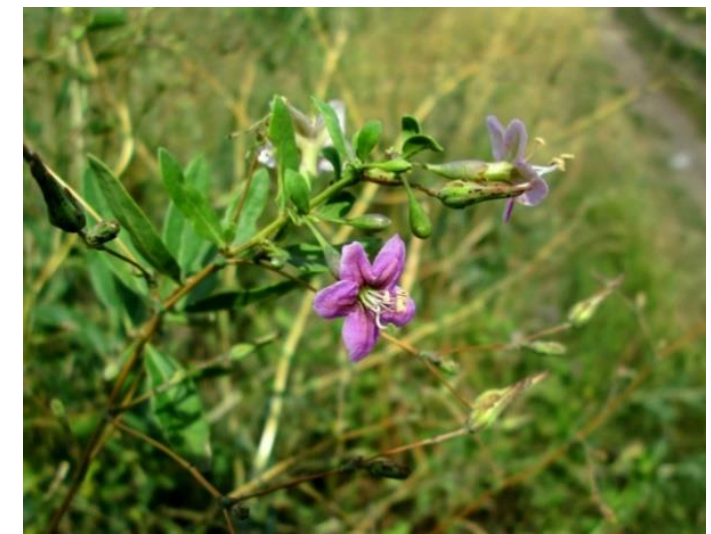

Photo 5. Lycium barbarum L.

The state of natural pastures. The yield of adjacent natural pastures of "Altinbaev Yeri" farm in the conditions of 2019 amounted to $10-20 \mathrm{~kg} / \mathrm{ha}$ and consists of poorly eaten plants, mainly Hulthemia persica, which makes up about $60-70 \%$ of the grassland. Such valuable fodder species as Poa bulbosa, Bromus tectorum, Carex pachystulis, Agropyrum orientale are present in the vegetation cover. The 
venomous perennial plant Trichodesma incanum D.C is found in some places. The projective cover of natural pastures is $15-20 \%$.

Productivity of fodder plants. On agrophytocenoses, the projective cover of vegetation is $85-90 \%$. The height of the Ceratoides eversmanniana plants is $75-90 \mathrm{~cm}$, the Kochia prostrata of $85-125 \mathrm{~cm}$, the yield of forage mass of Ceratoides eversmanniana in the conditions of 2019 was 1.6-1.8 t/ha, the Kochia prostrata of 1.6-2.0 t/ha, the seed yield of crops $120-130 \mathrm{~kg} / \mathrm{ha}$.

\section{Benefits of introducing technology:}

Ecological - Biodiversity of vegetation, animals and birds is increasing in the inter-strip spaces. The application of these methods allows increasing the forage reserve of pastures by 2-3 times. The slopes of the hills prone to water erosion are strengthened, the water regime improves, and the upper fertile layer of the earth remains.

Carbon sequestration: The plantings created will allow the use of pastures in all seasons of the year, increase soil fertility, sequestration of CO2 $-480 \mathrm{~kg}$ per $1 \mathrm{ha}$, and improve the environment

Economic - shrubs and semi shrubs are autumn-winter animal feed, form a crop of up to 1.8-2.0 t/ha. For 2-3 years, seeds are formed that can be sold and used plant phytomass. About 180-200 kg of hay for one sheep are needed to cover the costs of purchased feed, create guaranteed insurance reserves (without a grazing winter period of 90 days). For 100 goals, it is necessary to improve 10 hectares of pasture, to receive about 20 tons of dry weight.

Conclusions. The desert pastures of Uzbekistan, being part of the pastorals of Uzbekistan, are based on low-productivity pastures and occupy a special place in the country's economy as the main means of economic development of deserts, and at the same time they are the main source of livelihood and wellbeing of the population living here.

The ecological and biological potential of fodder plants determines the productivity of desert pastures in the range of $0.18-0.35 \mathrm{t} / \mathrm{ha}$.

At the same time, under the influence of mainly anthropogenic and other factors, there is an exposure of the earth's surface, disturbance of pasture plots, the disappearance of Astragalus and Onobrychis horossanica from the ecosystem - significantly reduces the laying of nitrogen in the soil. Thus, violation of the species structure of ecosystems reduces pasture biodiversity and negatively affects the environmental situation. To increase the productivity of pastures, preserve biodiversity, it is necessary to introduce promising species of fodder plants, use the seed crop to restore degraded pasture ecosystems.

\section{REFERENCES}

1. Asliddinov S. Study of the collection of Artemisia from the subgenus Seriphidium as a source material for selection. // Materials of the All-Union meeting "Status and prospects of breeding and introduction of fodder plants for desert and semi-desert zones" Samarkand, 1979, p. 37-39. (russ)

2. Gaevskaya LA, Salmanov N. Pastures, deserts and semi-deserts of Uzbekistan and ways of their rational use. Tashkent, 1975, $140 \mathrm{p}$. (russ)

3. Khaydarov Kh., Nurullaeva N. Morphological ontogenesis structure (lycium barbarum 1.) in the conditions of Samarkand region. SRM 2020, Denver, USA, Poster Abstracts, p 169

4. Mallaev Sh., Islomov B., Amirchanov N. About the introduction of Cousinia umbrosa under the semi desert and irrigated zones of Uzbekistan XYI International Botanikal Congress Abstract Submission from USA, Volume1,\#16, 45 p.

5. Mukimov T.Kh. and other. Ways to improve the efficiency of desert-pasture livestock in Uzbekistan. Perspective directions of sustainable development of the agricultural economy. Novosibirsk, 2014, 128-131 s. (russ)

6. Mukimov T., Khaydarov Kh., Mukhtasov S. Conservation and restoration of biodiversity of pasture ecosystems of the Adyr zone of Uzbekistan Ozik-ovqat hafslizigi: milliy wa global omillar khalkaro ilmiy-amaliy conference materiallari tuplami, Samarkand, 2019, 191-193 p. (russ)

7. Rabbimov A. Biological features and selection of Kochia prostrata (L) Schrad izen in the arid zone of Uzbekistan. Thesis of Diss., Leningrad. 1989, 17 p. (russ)

38 | P a g e 